\title{
PRODUCTIVE ZAKAT DISTRIBUTION MODEL IN BAZNAS OF WEST JAVA PROVINCE AND RUMAH ZAKAT OF BANDUNG
}

\author{
Neneng Nurhasanah \\ Sharia Faculty, Pascasarjana Universitas Islam Bandung \\ Jl. Purnwarman No. 59 Bandung \\ nenengnurhasanah@unisba.ac.id
}

\begin{abstract}
This study aimed at comparing the productive zakat distribution model of BAZNAS of West Java Province and Rumah Zakat, their constraints, and efforts conducted in optimizing productive zakat distribution. The study used comparative descriptive method. The results proposed that the productive zakat distribution model of BAZNAS was more varied than at Rumah Zakat's. BAZNAS conducted traditional consumptive, creative consumptive, traditional productive, and creative productive model using the system of in kind, Al-Qardhul Hasan, and Mudharabah (Revolving Fund System). Meanwhile, there was only one program at Rumah Zakat, namely working capital program to MSMEs handed over directly to Mustahiq, including creative productive zakat distribution. The obstacles faced by BAZNAS was limitations of Mustahiq's condition so that it took a long time to increase them to Muktafi and then Muzakki. Besides mindset and condition, Rumah Zakat faced capital and market obstacles. Mustahiq's training and assistance programs were efforts made by these agencies.
\end{abstract}

Keywords: Model; Distribution; Productive Zakat

\section{Introduction}

Zakat for Muslims has vertical and horizontal dimension. The former dimension means the manifestation of faith in God's commands to issue part of muslims properties when they have achieved nishab. The latter dimension means the importance awareness of helping fellow human beings in the form of social and economic activities.

The existence of zakat in economic growth is proven to have an extraordinary impac (Rachman \& Makkarateng, 2021) such as helping reduce unemployment and 
poverty. Some results of study concluded that the potential of zakat in Indonesia was very big as stated by the Chairman of Amil Zakat Agency, Prof. Hansel Bambang Sudibyo, MBA., Ca. in the 2019 National Zakat Statistics in May 2020.

The average growth of five-year zakat collection was at the rate of $25.7 \%$ and the national zakat collection in 2019 counted to 10.2 trillion with a comparison of distribution for national zakat collection in $84.57 \%$, or has effective value, referring to the categorization of Zakat Core Principles. According to Managing Director of Amil Zakat Agency, the data showed an increase in zakat management in Indonesia which continues to grow every year. It was characterized by increasing the innovation and creativity committed by Zakat Management Organization in zakat campaign as a form of da'wah, and the invitation to the community and in the distribution programs.

Zakat distribution is not only consumptive to fulfill the Mustahiq's (zakat beneficiaries) needs directly, but also be productive to help the sustainability of the fulfillment of their economic needs through education, business, and other productive activities. Productive zakat is distributed to Mustahiq that is managed and used for business capital to increase the economic level of Mustahiq (Abdullah, A: 2015). The definition of productive zakat also includes zakat treasures that are managed and developed by Amil whose results are distributed to Mustahiq regularly.

The implementation of productive zakat distribution still experiences some obstacles. First, most of Mustahiq are not worthy of trustworthy, technically, operationally, and especially morally, hence efforts to manage zakat independently become an option. Second, this distribution has not been a priority that is taken into account in Indonesia and countries with a majority of Muslims who have the same fate. Third, it is rarely introduced or deliberately recommended by the existing amil agencies because technically consumptive zakat distribution is much easier to fulfill both procedures and accountability (Zalikha, 2016).

Some research shows that the fund of productive zakat distribution has no significant effect on the profits and income of Mustahi (Farid, 2015). This distribution affects the growth of Mustahiq's microbusiness, but not on the welfare (Shobah \& Rifai, 2020). Besides empowering professional managed zakat agencies will be able to overcome all things that cause poverty (Nasution, Nisa, Zakariah, \& Zakariah, 2018).

In Indonesia, two zakat management agencies have received 
legitimacy both from the government through various regulations and from the community in the form of trust to manage zakat (accept and distribute zakat to the right parties). Those agencies are Badan Amil Zakat (BAZ) and Lembaga Amil Zakat (LAZ). They distribute productive zakat with different schemes and programs.

Some studies concluded that there was no optimal productive zakat distribution in increasing Mustahiq's revenue or economic life sustainability. Hence, this study was conducted to know more about the productive zakat distribution model carried out by the two zakat management agencies and the obstacles faced by them. The results can be used for knowing how those agencies distributed the more effective model that provides benefits to Mustahiq. Therefore, the purpose of this study was to analyze the productive distribution model in BAZ and LAZ, and the comparison of obstacles and efforts in implementing this distribution in encouraging the improvement of Mustahiq's economic life (Sumiyati, Hendar, Ramli, \& Mufidi, 2018).

The method used in this study was descriptive analysis including a type of qualitative research aiming at understanding the productive zakat distribution model of two zakat management agencies in Indonesia, and comparing them (Suprayogo \& Tabroni, 2001). Therefore, its data was naturalist using inductive logic, and its report was descriptive. Field study was conducted by selecting BAZ of West Java Province and Rumah Zakat of Bandung City. They were chosen because they were in accordance with the objectives, namely to examine the productive zakat distribution model in two zakat management agencies that have this program or scheme.

Data collection was conducted directly to the site by interviewing and conducting descriptive observation to study the productive zakat distribution model and obstacles and success achieved by these agencies (Bogdan \& Taylor, 1975, p. 33) besides the documentation technique, which is a written record of events related to Institutional Zakat Agencies (Sugiyono, 2009, p. 329).

Interviewing to the leader of BAZ of West Java Province and Rumah Zakat of Bandung City aimed at hearing their information about the problems surrounding the conducted productive zakat distribution carried out that they knew (Adam, 1952, p. 5). Furthermore, the data was analyzed interactively and continuously to thoroughly dissect the practice of the productive zakat distribution in the BAZ of West Java Province and Rumah Zakat of Bandung City 


\section{Discussion}

\section{A. Productive Zakat Distribution Model in Zakat Agencies}

Productive zakat is zakat distribution model that can make Mustahiq produce something continuously with zakat treasure that has been received. Productive zakat is the treasure of zakat given to Mustahiq by not being spent or consumed, but was used and developed to help their efforts, so that they could meet their life needs continuously (Asnaini, 2008, p. 64). Productive zakat means to make zakat money not only consumptive, but also is used for business capital to be able to alleviate poverty of Mustahiq who did not spend the received zakat, but they used and developed it to help their business sustainably. Through this business capital, Mustahiq was expected to be immortalized to be Muzakki someday (Ali \& El Ayyubi, 2016).

Abdullah (2013) says that productive zakat was given to the poor in the form of business capital or productive businesses that would improve their standard of living, with the hope that Mustahiq will be able to become Muzakki. While Anwar (2018) states that the development of zakat is productive by making zakat funds as a business capital, for the economic empowerment of the recipients, and so that the poor people can carry out or pay their lives consistently. With zakat funds, the poor people will get permanent income, increase businesses, develop businesses, and set aside their income to save.

Productive zakat is distributed to Mustahiq in a proper way, in effective benefits with a versatile and productive system, and in accordance with the message of the law and the participation of socioeconomic functions of zakat. Mustahiq who receives zakat distribution productively, does not spend it. He develops and uses it to help his efforts, so that zakat funds can make him produce something sustainably (Shobah \& Rifai, 2020, p. 523) including in the sense of productive zakat if zakat treasure is managed and developed by Amil whose results are distributed to Mustahik regularly (Zalikha, 2016, p. 308).

According to Rusli and Syahnur (2013)in terms of the classification of distribution, productive zakat funds are divided into two parts: conventional productive zakat and creative productive zakat. The former can be given in the form of productive or developed goods. Mustahiq must have creativity in creating a new business that has good prospects in the future, such as animal-raising, opening a clothing convection business, opening a haircut business, and others. The latter is 
implemented in the form of business capital, both for the construction of social activities projects, as small and medium micro business capital, and the development of business economy of traders in markets or small entrepreneurs (Asnaini, 2008).

The productive zakat distribution is divided into two forms. First, zakat is handed over directly to Mustahiq to be utilized, meaning that 'ayn al-zakah that is given to Mustahiq so that zakat becomes fully self-owned rights of Mustahiq. This distribution is also called non-investment productive zakat distribution (Zalikha, 2016). Mufraini (2006)says that this distribution consists of two models: (a) zakat that is given in the form of cash or replacement from zakat objects that is used as business capital. The nominal is adjusted to the Mustahiq needs to get a profit from the business; (b) zakat that is given in the form of items the main tool work that can be developed, such as goats, cattle, shavers, sewing machines, and others.

Second, the productive zakat distribution that is developed now is investment, namely zakat that is not directly handed to Mustahiq. In other words, mustawlad al-zakah that is given to Mustahiq (Mufraini called it creative productive zakat). This kind of distribution also consists of two models, namely: (a) providing business capital to Mustahiq by taking turned throughout Mustahiq and (b) building social projects and economical projects, such as building facilities for work for prosecutors and others.

Mufraini (2006, p. 147) explains in more detail that the innovation form of zakat distribution is categorized in four forms. First, the traditional consumptive distribution is distributed to Mustahiq directly, such as zakat fitrah, or zakat mall distributed to the victims of natural disasters. Second, the creative consumptive distribution is realized in the other forms of its original items, such as school tools or scholarships. Third, the traditional productive distribution is given in the form of productive items such as goats, cattle, and so on, so that they can create an effort to open employment for the poor. Fourth, the creative productive distribution is manifested in a business capital to increase the capital of small businessman traders or build social and economical projects.

Zakat productive distribution is in the form of investment, especially giving the capital given in turn rolled to Mustahiq. Its capital status is not an individual property or belongs to Amil or agencies, but belongs to Mustahiq because the funds should not be included in the Al-Mal Cash 
to be saved. This distribution system is more frequently practiced through 'aqad qard al- hasan, 'aqad mudarabah dan 'aqad murabahah (Zalikha, 2016, p. 309).

In line with this, in this modern era, there are some systems in creative and innovative zakat distribution model (Muharom, 2010). First, in kind system model is zakat given in the form of production equipment needed by poor Mustahiq who wants to conduct business both just starting a business and develop the existing business (Mas'ud \& Muhammad, 2005, p. 123). Second, al-Qardhul Hasan system model is a form of loan determining not an extinction of certain returns or profit sharing from the loan principal (Mufraini, 2006, p. 160). The loan or capital principal is returned by Mustahiq to Amil Zakat agencies, but the capital still belongs to Mustahiq that can be reproduced by Mustahiq for the addition of further business capital, or the accumulated return funds are given to Mustahiq in another in order. With this model, it is expected that the zakat agencies become a Mustaqiq partner in developing its business so that it comes out of its conscience. This model is also called the Revolving Fund system (Mas'ud \& Muhammad, 2005, p. 124). Third, the mudharabah system is almost the same as Al Qardh Al Hasan. Their difference is on the profit sharing of the business between Mustahiq and Amil (Mufraini, 2006, p. 167).

Productive zakat in its implementation is managed through two zakat agencies as stipulated in Law Number 23 Year 2011 concerning Management of Zakat. First, Badan Amil Zakat Nasional (BAZNAS/National Amil Zakat Agency) is located in the capital city, province, and district/city. BAZNAS can form an organizational unit of Unit Pengumpul Zakat (UPZ/Zakat Collector Unit) to help collect zakat. BAZNAS is a non-structural government agency that is independent and responsible for the President through the minister who is authorized to carry out the task of managing zakat nationally.

Second, Lembaga Amil Zakat (LAZ/Amil Zakat Institution) is formed by the community who has the task of helping BAZNAS in the collection, distribution, and utilization of zakat. LAZ's formation must get the permission of the minister or official appointed by the minister. LAZ must report regularly to BAZNAS for the implementation of the collection, distribution, and utilization of zakat whose shariat and finance have been audited (Peraturan BPK: Undang-undang Nomor 23 Tahun 2011, 2011). 
Management of zakat conducted by those two agencies is in the form of planning, implementation, and coordinating in the collection, distribution, and utilization of zakat. Productive zakat distribution is in the distribution and utilization of zakat to the Mustahiq managed and developed through business behavior and assets management to be used as capital to improve the economic level of Mustahiq. Its distribution method consists of two forms: (1) the non-investment productive zakat distribution, which is the zakat submitted directly to the Mustahiq to be utilized, so that zakat becomes a fully self-owned right, meaning that the zakat given to Mustahiq is 'ayn al-zakah; (2) the investment productive zakat distribution is the zakat submitted not directly to Mustahiq, meaning that the zakat given to Mustahiq is mustawlad al-zakah (Zalikha, S. 2016).

Productive zakat management must be accompanied by coaching and assistance activities to the Mustahiq, so that the business activities can run well (Hafidhuddin, 2002, p. 133)because the main objectives of productive zakat management is to transform a Mustahiq to be a Muzakki. To reach the level of Muzaki, a Mustahiq must be transformed in stages. Initially, a Mustahiq is transformed into a Muktafi (people who could meet their own needs). At this stage, a Muktafi has not been able to share with others, but has been able to be independent. The transformation from Mustahik to Muzaki requires a process and consistency in their efforts.

\section{B. Productive Zakat Distribution at}

\section{BAZNAS}

This study presents how the productive zakat distribution was conducted in two zakat management agencies as stipulated in Law Number 23 Year 2011 concerning Management of Zakat, namely BAZNAS and LAZ. The agencies taken for this study were BAZNAS of West Java Province and LAZ Rumah Zakat of Bandung City, which have productive zakat distribution program.

BAZNAS of West Java Province is located at Jl. Soekarno Hatta No. 458, Batununggal, Bandung Kidul, Bandung 40266. It manages zakat funds, infaq and qurban that are distributed in the form of regular and incidental programs. Regular program is the routine activities with the same or different Mustahiq, while incidental program is conducted once in a year. Zakat funds that have been collected are distributed to all regions of West Java and in collaboration with Central BAZNAS, BAZNAS in the city or district, Amil Zakat Institution (LAZ), Lembaga Pemberdayaan Masyarakat (LPM/Community Empowerment 
Institutions), and Muzaki Recommendations (Donors) by keeping the sharia procedure and rules (Program Jabar).

BAZNAS of West Java Province distributes zakat funds in five program fields, namely: economics, education, health, religion, and humanity. Zakat funds distribution is conducted with a personal and community approach. Zakat funds compiled by BAZNAS are distributed to eight groups asnaf who has the right to receive zakat or Mustahiq .

Zakat funds distribution to Mustahiq in the consumptive form consists of (a) direct distribution to Mustahiq carried out in the Mustahiq service office, (b) distribution conducted by BAZNAS in the city or district in the form of a disaster response synergized with BAZNAS in the province in its distribution (BAZNAS in the city or district submits a recommendation of beneficiaries according to the asnaf zakat, after obtaining a notification letter about the program from BAZNAS of West Java Province. Then, BAZNAS in the city or district conducts Mustahiq's selection, field survey, and verification based on the work instructions for funds zakat distribution), and (c) humanitarian assistance program named BAZNAS Tanggap Bencana (BTB/BAZNAS Disaster Response) Regular in West Java prepares funds and human resources that are trained to contrbute to respond to conditions that occur.

This program aims at preparing for ready and tough human resource volunteers, accelerating disaster response at the level of West Java Province, training vigilance to minimize the negative impact of disaster, and building independence through assistance in the form of disaster response villages. (d) Healthy Car Service in the form of assistance provided as a form of concern for BAZNAS of West Java Province to people who are less able to access ambulances to mobilize their routine treatment and incidental needs (Alkahfi, Taufiq, \& Meutia, 2020).

Productive zakat programs run through programs named Jabar Mandiri, such as zakat distribution program in the form of pre-business incubation program for Sumedang Mustahiq farmers at UPTD BPPDK Margawati, fish aquaculture program in buckets carried out by Mustahiq group in Cimahi City, Training of Making Frozen Food for Mustahiq assisted by BAZNAS of West Java in Bandung City, and Cooking Class program which lasted four months for MSMEs in Sukabumi City. Community Empowerment provides assistance in the form of business capital in Program Wirausaha Mandiri (Mandiri Entrepreneurial Program). Communitybased BAZNAS empowerment programs 
were conducted in West Java Province, especially in areas where the economic conditions of the people are still weak. Its purpose is to improve economic capacity and the independence of the community who still live below the poverty line, such as in Cibuluh Batik Village in Cibuluh Village, North Bogor Regency, West Java.

Other programs are Jabar Sehat, for example conducting Ngaji Lansia and special health services for elderly in three districts in West Java, namely Cikajang Village at Garut Regency, Cupupara Village at Subang Regency, and Cibogo Village at West Bandung Regency with a target of 300 beneficiaries. Besides that, Jabar Cerdas is a program organized by Lembaga Beasiswa BAZNAS (LBB/BAZNAS Scholarships Institutions) of West Java in collaboration with DPM Village of West Java and Patriot Village. This program aims at reducing the dropout figures especially for adolescent, for example, Desa Cerdas BAZNAS program in Tanjungjaya Village, Banjarwangi District, Garut Regency. Additionally, Jabar Peduli is a program for helping residents because of disaster affected such as floods, tornadoes, and Covid 19.

The productive zakat distribution program in BAZ of West Java Province is conducted in a traditional consumptive, creative consumptive, traditional productive, and creative productive form. The model uses the system of in kind, alqardhul hasan, and mudharabah (Mufraini, 2006, p. 167) as known as Revolving Fund system (Mas'ud \& Muhammad, 2005, p. 124). In general, there is an influence between giving capital assistance to the development of capital, turnover, and profits before and after receiving business capital assistance as happened at BAZ Semarang City (Wulansari \& Setiawan, 2013).

The obstacle experienced by BAZ team was to determine Mustahiq because Mustahiq is the person who really must be empowered from zero, so that it takes a long time to become Muzakki. Even though there have been provisions regarding had kifayah, in practice, there are still Mustahiq whose criteria are above the provisions, for example the person has already had livestock, but still gets zakat assistance. Giving benefits to a person whose criteria do not included as Mustahiq, often becomes a dilemma but it is easier to empower him or her (Firmansyah, Alamanda, \& Santoso, 2020).

The determination and condition of Mustahiq become an obstacle, while the $\mathrm{BAZ}$ empowerment team is required to provide progress as fast as possible (Ihsan Habibullah, July 12, 2021). The size of Mustahiq is its had kifayah or the limit of 
sufficiency or the basic standard of someone/family needs plus the adequacy of existing dependents to establish the feasibility of the zakat recipient according to the conditions of the region and socioeconomic local economy. For West Java, the results of BAZNAS had kifayah is Rp. $1,885,411$.

\section{Productive Zakat Distribution at Rumah Zakat of Bandung City (LAZ)}

Rumah Zakat is one of the zakat management agencies originating from the community, with the head office at $\mathrm{Jl}$. Turangga No. 33 Bandung. Rumah Zakat is a philanthropic institution managing zakat, infaq, alms, and other social funds through community empowerment programs. The programs are realized through four main clumps, namely the Senyum Juara (education), Senyum Sehat (health), Senyum Mandiri (economic empowerment), and Senyum Lestari (environmental sustainability initiative).

Integrated programs including the fields of economics, education, health, and the environment are realized in Desa Berdaya program. It can be said as the empowerment program in the scope of village area through an integrated approach ranging from capacity building program, economics, education, health, environment, to disaster preparedness with the growing target and the development of local institutions are empowered to overcome their own problems and collaborate with other parties, especially the village government. Desa Berdaya program is empowered from zakat funds, infaq, and alms of Rumah Zakat donors.

The purpose of Desa Berdaya program is, first, the formation of community empowerment or the strengthening of community institutions in the economic sector in the various form of BUMMas (Badan Usaha Milik Masyarakat or community-owned enterprises) and, second, the increasing knowledge, motivation, and skills of individual empowerment in the implementation of certain sectors (education, health, and environment), which affect the improvement of welfare.

Desa Berdaya program includes four main clumps. First, Senyum Juara is an educational empowerment program aiming at making improvements to educational quality including beneficiary categories: students, infrastructure, and quality students in accordance with the objectives of SDGs (Sustainable Development Goals) ensuring that all Indonesian children complete elementary and secondary education freely, evenly distributed, and qualified that leads to the impact of relevant 
and effective learning. One of them is Beasiswa Juara program, which supports 10,000 orphaned and dhuafa foster children to obtain appropriate education including being utilized to overcome the issue of children's education in Palestine.

Senyum Mandiri is a local potentialbased economic empowerment program for poor society to reduce poverty. The Bangkit MSME program is the provision of business capital to small micro entrepreneurs, such as egg traders, stalls, and others.

Senyum Sehat is a program to improve the quality of individual, communal, and self-help public health. The realization of this program is in the form of Ramah Lansia (Elderly Friendly), Posyandu Balita (Service for Toddlers), Khitanan Massal (Mass Circumcision), Ambulance Gratis (Free Ambulance), Siaga Sehat (Healthy Standby), Bantuan Kesehatan (Health Assistance), Kebun Gizi (Nutritional Gardens), and Klinik Gratis (Free Clinics).

The health program that has been realized is a maternity home clinic building that has a vision to form a healthy society in a plenary, so that it is able to be productive and beneficial to the whole world. This Rumah Bersalin Gratis (RBG/Free Maternity House) began to be pioneered since 2006 . There are currently eight RBG clinics that have been established in the territory of Indonesia such as in Bandung, Jakarta, Medan, Pekanbaru, Semarang, Surabaya, and Yogyakarta. Other programs are food direct distribution to the poor in both necessities and food; humanitarian assistance in the form of assistance to the affected community of floods, landslides, earthquakes, and others, including Palestinians. It also helps volunteers in handling the prevention of the spread of Covid virus 19.

Senyum Lestari is a program focused on environmental problems, Rumah Zakat is committed to improving environmental quality, reducing social issues related to the environment, especially water, sanitation and cleanliness, and distributing to a place that is prone to clean water.

The form of productive zakat distribution at Rumah Zakat is in the program of giving work capital to MSMEs such as egg traders and small stalls, which are handed over directly to Mustahiq or 'ayn al-zakah, meaning that the zakat belongs to Mustahiq. This distribution includes the non-investment productive zakat distribution as known as creative productive, meaning that the zakat is manifested in a form of capital for adding the capital of smaller entrepreneurs or 
traditional productive. Most of the zakat distribution is still traditional consumptive, meaning that the zakat is shared with Mustahiq to be used directly, such as zakat fitrah or zakat mall distributed to victims of natural disasters. Some of them are also creative consumptive, meaning that the zakat is realized in the other forms of its original items, such as in the form of scholarships. However, there is no distribution that is traditional productive, meaning that the zakat is given in the form of productive items, such as goats, cattle, and so on.

The obstacles faced by Rumah Zakat team in distributing productive zakat were Mustahiq's mindset and capacity, capital, and market. To respond to obstacles related to Mustahiq's mindset and capacity, Rumah Zakat made mentoring and training activities to foster Mustahiq's enthusiasm and capacity as traders and entrepreneurs. Besides that, to overcome capital, Rumah Zakat elaborated ZISWAF (Financial Blanded) funds, accessed the business world, and adjusting the amount of capital with business opportunities. In addition to overcome market, Rumah Zakat helped market accessed through collaboration with digital ecosystems such as e-comers and other digital platforms and collaboration between MSMEs (Nur Efendi, CEO of Rumah Zakat, 14 July2021).

\section{Conclusion}

The productive zakat distribution model at BAZNAS of West Java Province was conducted more varied than at Rumah Zakat of Bandung City. The productive zakat distribution program in BAZ of West Java Province was carried out in the form of traditional consumptive, creative consumptive, traditional productive, and creative productive. Their model used the system of in kind, al-qardhul hasan, and mudharabah, as known as Revolving Fund system. Meanwhile, besides in the form of creative consumptive, Rumah Zakat distributed creative productive zakat in the form of working capital programs to MSMEs that are handed over directly to Mustahiq.

The obstacles faced by BAZ of West Java Province were more concerned about the conditions of Mustahiq who has limitations so that it took a long time to increase them to Muktafi stage (people who can meet their own needs), moreover to Muzakki stage. Nevertheless, Rumah Zakat aced the same problems such as Mustahiq's mindset and capacity, and also capital and market constraints. Training and assistance programs found the access to capital and business markets Mustahiq is efforts made by the BAZ of West Java Province and Rumah Zakat in facing these obstacles. 


\section{Bibliography}

Abdullah, A. (2017). Strategi Pendayagunaan Zakat Produktif. Al-Mashlahah Jurnal Hukum Islam dan Pranata Sosial , 1 (0).

Abdullah, A. (2013). Strategi Pendayagunaan Zakat Produktif Studi BAZ Kabupaten Sukabumi Jawa Barat. Al-Mashlahah: Jurnal Hukum Islam dan Pranata Sosial Islam , 1 (1), 1-13.

Adam, L. (1952). Method and Forms of Infestigation and Recording of Native Customary Law in The Netherlands East Indies before the War. Oxford: Oxford University Press.

Ali, K. M., \& El Ayyubi, S. (2016). Perbandingan zakat produktif dan zakat konsumtif dalam meningkatkan kesejahteraan mustahik. 4 (1), 19-32.

Alkahfi, B. D., Taufiq, T., \& Meutia, I. (2020). Pengaruh akuntansi zakat terhadap akuntabilitas publik (Studi kasus di Badan Amil Zakat Nasional (BAZNAS) dan Lembaga Amil Zakat (LAZ) Kabupaten/Kota Provinsi Sumatera Selatan). Amwaluna: Jurnal Ekonomi dan Keuangan Syariah , 4 (1), 112-126.

Anwar, A. T. (2018). Zakat Produktif untuk Pemberdayaan Ekonomi Umat. ZISWAF:Jurnal Zakat dan Wakaf, 5 (1), 41-62.

Asnaini. (2008). Zakat Produktif dalam Perspektif Hukum Islam. Yogyakarta: Pustaka Pelajar.

Bogdan, \& Taylor. (1975). Metodologi Penelitian Kualitatif. Bandung: Rosdakarya.

Efendi, M. (2017). Pengelolaan Zakat Produktif
Kewirausahaan Sosial dalam Pengentasan Kemiskinan di Indonesia. Al-Ahkam: Jurnal Ilmu Syari'ah dan Hukum , 2 (1), 2-38.

Farid, M. (2015). Analisis Dampak Penyaluran Zakat Produktif terhadap Keuntungan Usaha Mustahiq.

Firmansyah, E. A., Alamanda, A. R., \& Santoso, T. (2020). An evaluation of scholarly works in zakat: A bibliometric analysis of Islamic economics journals in Indonesia. Amwaluna: Jurnal Ekonomi dan Keuangan Syariah , 4 (2), 311-323. Hafidhuddin, D. (2002). Zakat dalam Perekonomian Modern (1 ed.). Jakarta: Gema Insani Press.

Mas'ud, R., \& Muhammad. (2005). Zakat \& Kemiskinan: Instrumen Pemberdayaan Ekonomi Umat. Yogyakarta: UII Press.

Mufraini, M. A. (2006). Akuntansi dan Manajemen Zakat. Jakarta: Prenadamedia Group.

Muharom, F. (2010). Model-Model Kreatif Distribusi Zakat Berbasis Masyarakat. Ijtihad: Jurnal Wacana Hukum Islam dan Kemanusiaan, 10 (1).

Nafiah, L. (2015). Pengaruh pendayagunaan zakat produktif terhadap kesejahteraan mustahiq pada program ternak bergulir BAZNAS kabupaten Gresik. ElQist , 5 (1), 317-321.

Nasution, A. H., Nisa, K., Zakariah, M., \& Zakariah, M. A. (2018). Kajian Strategi Zakat, Infaq Dan Shadaqah Dalam Pemberdayaan Umat. Jurnal Ekonomi Bisnis Syariah , 1 (1), 2237. 
Nidityo, H. G. (2014). Zakat Produktif untuk Meningkatkan Kinerja Produksi, Motivasi, dan Religiusitas Mustahiq (Studi Kasus pada BAZ Jatim). Jurnal Ekonomi Syariah Teori \& Terapan , 1 (9), 661-673.

Nopiardo, W. (2016). Mekanisme Pengelolaan Zakat Produktif pada Badan Amil Zakat Nasional Tanah Datar. Jurnal Ekonomi dan Bisnis Islam , 1 (2), 186-196.

Peraturan BPK: Undang-undang Nomor 23 Tahun 2011. (2011). Retrieved from

https://peraturan.bpk.go.id/Home/D etails/39267/uu-no-23-tahun-2011

Pratama, Y. C. (2015). Peran Zakat dalam Penanggulangan Kemiskinan (Studi Kasus: Program Zakat Produktif pada Badan Amil Zakat Nasional). Tauhidinomics , 1 (1), 93-104.

Program Jabar. (n.d.). Retrieved from https://www.baznasjabar.org/progr am-jabar

Program Jabar. (n.d.). Retrieved from https://www.baznasjabar.org/progr am-jabar

Rachman, A., \& Makkarateng, M. (2021). Sinergitas Organisasi Pengelola Zakat dan Wakaf dalam Pembangunan Ekonomi di Indonesia. Al-Kharaj , 1 (1), 1-19.

Rusli, A. H., \& Syahnur, S. (2013). Analisis Dampak Pemberian Modal Zakat Produktif terhadap Pengentasan Kemiskinan di Kabupaten Aceh Utara. Jurnal Ilmu Ekonomi Pascasarjana Universitas Syiah Kuala , 1 (1), 56-63.

Shobah, A. N., \& Rifai, F. Y. (2020). Konsep Ekonomi Islam dalam Peningkatan Kesejahteraan
Mustahiq melalui Zakat Produktif (BAZNAS) Kabupaten Purworejo. Jurnal Ilmiah Ekonomi Islam , 6 (3), 521-528.

Statistik Zakat nasional. (2019). Retrieved from https://pid.baznas.go.id/wpcontent/uploads/2020/09/STATIST IK-ZAKAT-NASIONAL-2019.pdf Sugiyono. (2009). Metode Penelitian Pendidikan (Pendekatan Kuantitatif, Kualitatif, dan $R \& D$ ) (IX ed.). Bandung: Alfabeta.

Sumiyati, Y., Hendar, J., Ramli, T. A., \& Mufidi, M. F. (2018). Kriteria kepatutan dan kewajaran dalam tanggung jawab sosial perusahaan menurut hukum Islam. Amwaluna: Jurnal Ekonomi dan Keuangan Syariah , 2 (1), 58-68.

Suprayogo, I., \& Tabroni. (2001). Metode Penelitian Sosial Agama. Bandung: Remaja Rosda Karya.

Wulansari, S. D., \& Setiawan, A. H. (2013). Analisis Peranan Dana Zakat Produktif terhadap Perkembangan Usaha Mikro Mustahik (Penerima Zakat)(Studi Kasus Rumah Zakat Kota Semarang). Unpublished.

Zalikha, S. (2016). Pendistribusian Zakat Produktif dalam Perspektif Islam. Jurnal Ilmiah Islam Futura, 15 (2), 304-319. 